\title{
Molecular Docking Analysis of Ficus religiosa Active Compound with Anti-Inflammatory Activity by Targeting Tumour Necrosis Factor Alpha and Vascular Endothelial Growth Factor Receptor in Diabetic Wound Healing
}

\author{
Yuyun Yueniwati ${ }^{1 *}$ (D), Mokhammad Fahmi Rizki Syaban ${ }^{2}$ (D), Nabila Erina Erwan ${ }^{3}$ D, Gumilar Fardhani Ami Putra ${ }^{3}$, \\ Agung Dwi Krisnayana² \\ ${ }^{1}$ Department of Radiology, Faculty of Medicine, Universitas Brawijaya, Saiful Anwar Hospital, Malang, Indonesia; ${ }^{2}$ Department \\ of Medicine, Faculty of Medicine, Universitas Brawijaya, Malang, Indonesia; ${ }^{3}$ Department of Biomedical Science, Faculty of \\ Medicine, Universitas Brawijaya, Malang, Indonesia
}

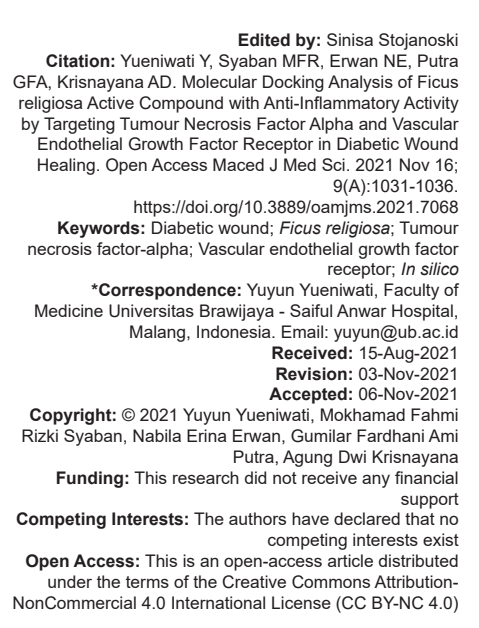

Abstract

BACKGROUND: Diabetes mellitus contributes to the delayed healing of wounds causes disturbance of inflammatory cytokine. Tumour necrosis factor alpha (TNF-alpha) and Vascular Endothelial Growth Factor Receptor (VEGFR) both have a role in the persistent inflammation associated with diabetic wounds. Ficus religiosa has developed a reputation as a traditional wound healer among some java people in Indonesia.

AIM: Our study aims to discover the molecular interaction between the active constituents of $F$. religiosa with TNFalpha and VEGFR.

MATERIALS AND METHODS: This research was conducted in computerized molecular docking using Protein database, Pymol, Discovery studio, and Pyrex software. A thorough literature search was conducted to identify the potential compound and molecular target for diabetic wounds. Analysis of its anti-inflammatory properties was also carried out using a passonline webserver. Pharmacokinetic analysis was performed using the Lipinski Rule of Five websites and the PreADMET website.

RESULTS: Each of the study's active compounds has a good pharmacokinetic profile. The predictions of the compound's structure indicate that it has a strong anti-inflammatory impact. Lupenyl acetate and Lanosterol bind more strongly to the TNF-alpha than the natural ligand, but Piperine binds more strongly to VEGFR.

CONCLUSIONS: Lupenyl acetate, Lanosterol, and Piperine compounds have anti-inflammatory effects through inhibition of TNF-alpha and VEGFR. In addition, this compound has potential to become a drug because it has good pharmacokinetics. Future studies are required to determine the effectiveness and toxicity of Lupenyl acetate Lanosterol, and Piperine as potential treatment in diabetic wounds.

\section{Introduction}

Diabetes mellitus (DM) is a group of metabolic diseases characterized by hyperglycemia that occurs due to abnormalities in insulin secretion, insulin action, or both. World Health Organization has predicted an increasing number of people with diabetes in Indonesia from 8.4 million in 2000 to around 21.3 million in 2030. At the same time, the International Diabetes Federation predicts that there will be an increase in the number of people with DM in Indonesia from 9.1 million in 2014 to 14.1 million in 2035 [1]. These data show that the number of people with DM in Indonesia is vast and is likely to increase rapidly in the future.

The wound healing process consists of several stages: hemostatic, inflammation, proliferation, and remodeling. In people with $\mathrm{DM}$, the process of wound healing is impaired, one of which is due to the disturbance of inflammatory cytokines. This disturbance will make the wound healing process in DM sufferers longer and more complicated [2]. In an immunocompromised condition like $\mathrm{DM}$, the pro-inflammatory phenotype may be induced by a hyperglycemic state. The condition leads to increased oxidative and inflammatory stress via pro-inflammatory cytokine and reactive oxygen species [3].

Among widely beneficial activities, the inflammation-regulatory effect and wound healing activity became a concern of in silico study. As recognized beforehand, Tumour Necrosis Factor alpha (TNF-alpha) is a potent pro-inflammatory cytokine in the inflammatory process [4], [5]. Previous studies discovered that local increment of TNF-alpha might positively affect the wound healing process, proving that regulation of inflammatory activity is helpful in the acceleration of wound healing. The inflammationregulatory effect was appraised by targeting TNF-Alpha as a macromolecule [3], [4]. 
Vascular Endothelial Growth Factor Receptor (VEGFR) had been studied concerning impaired wound healing in diabetic conditions. VEGFR was found to be damaged in type $1 \mathrm{DM}$ with slow perfusion recovery. In diabetic mice with experimental peripheral artery disease, glycaemic control was found in conjunction with improved VEGFR protein expression. Correlation between VEGFR and wound healing, specifically in diabetic conditions, might indicate its usefulness as a therapeutic target in diabetic wound healing [6].

Plants contain phytochemicals such as tannins, saponins, and flavonoids. These phytochemicals can also aid in the regeneration of cells and the healing of wounds [7]. This phytochemical, according to one study, can heal diabetic patients' wounds. Anti-inflammatory phytochemicals are found in the banyan tree (Ficus religiosa). The Banyan tree ( $F$. religiosa) is a highly phytochemical plant that grows widely in Indonesia, particularly in Java. Previous research has shown that the $F$. religiosa leaf has anti-inflammatory properties. Lupenyl Acetate, Lanosterol, Piperlongumine, Piperine, Quercetin, Kaempferol, Myricetin, and Methyl Piperate were the active ingredients have anti-anti-inflammatory properties [8]. Lanosterol had been found to modulate interferon-related inflammatory pathway, leading to better inflammatory response to bacterial invasion [9]. Study showed that piperlongumine is able to inhibit inflammation via nuclear factor kappa B (NF-KB) pathway [10]. Piperine had also been found able to inhibit inflammation in vitro and in vivo [11]. Quercetin was also proven to be able to inhibit inflammation via NF-kB pathway [12].

Nowadays, in silico method is used to evaluate the viability of a compound as a drug candidate. In silico simulation of drug interactions can predict the binding sites of the protein interaction mechanism and the bond energy that occurs [13], [14]. This research will indicate the molecular interaction process that occurs between two molecules using an in silico method. Using molecular docking, we will investigate this compound's anti-inflammatory effect.

\section{Materials and Methods}

\section{Compound search}

We were previously searching for an active compound with anti-inflammatory action, according to literature studies. The active compounds of F. religiosa analyzed were Lupenyl Acetate, Lanosterol, Piperlongumine, Piperine, Quercetin, Kaempferol, Myricetin, and Methyl Piperate based on previous research [8], [12], [15], [16], [17].

\section{Ligands and protein preparation}

The 3D structure samples of these compounds were obtained from PubChem (pubchem.ncbi.nlm.nih.gov). Lupenyl Acetate (CID: 6432150), Lanosterol (CID:246983), Piperlongumine (CID: 637858), Piperine (CID: 638024), Quercetin (CID: 5280343), Kaempferol (CID: 5280863), Myrecetin (CID: 5281672), and Methyl Piperate (CID: 9921021). The 3D structure is downloaded as a (.sdf) file extension.

The TNF-alpha target protein was downloaded from the Protein Data Bank (PDB) (rcsb.org) with protein code (PDB: 2AZ5) and VEGFR with code (PDB: 3HNG). The file was downloaded as a (.pdb) file extension. The target protein's optimization was then carried out by separating water residues and ligands using PyMOL 2.0 software. The remaining residue in the target protein will affect the bonding interaction between the protein and the ligand. It must be separated and stored in a.pdb file format before simulating the molecular interactions. We used native ligand inhibitors provided on the PDB website for comparison with compound ligands from $F$. religiosa [18], [19].

\section{analysis \\ Pharmacokinetic and anti-inflammatory}

The active compound obtained from the database was analyzed pharmacokinetically based on Lipinski Rules of Five using the SwissAdme (swissadme. ch) webserver. SwissAdme was used to conduct a pharmacokinetic study of these compounds by inputting the SMILE acquired from Pubchem into the web, as shown in Table 1 [8], [20]. We also did a prediction score for anti-inflammatory properties by utilizing the PASSonline server for estimated the likelihood value of the chemical acting as an anti-inflammatory (http:// www.way2drug.com/passonline/) [21].

Table 1: SMILE compound formula

\begin{tabular}{ll}
\hline Compound Name & $\mathrm{SMILE}$ \\
\hline Lupenyl acetate & $\mathrm{CC}(=\mathrm{C}) \mathrm{C} 1 \mathrm{CCC} 2(\mathrm{C} 1 \mathrm{C} 3 \mathrm{CCC} 4 \mathrm{C} 5(\mathrm{CCC}(\mathrm{C}(\mathrm{C} 5 \mathrm{CCC} 4(\mathrm{C} 3(\mathrm{CC} 2) \mathrm{C}) \mathrm{C})$ \\
& $\mathrm{C}) \mathrm{C}) \mathrm{OC}=\mathrm{O}) \mathrm{C}) \mathrm{C}) \mathrm{C}$ \\
Lanosterol & $\mathrm{CC}(\mathrm{CCC}=\mathrm{C}(\mathrm{C}) \mathrm{C}) \mathrm{C} 1 \mathrm{CCC} 2(\mathrm{C} 1(\mathrm{CCC} 3=\mathrm{C} 2 \mathrm{CCC} 4 \mathrm{C} 3(\mathrm{CCC}(\mathrm{C} 4(\mathrm{C})$ \\
& $\mathrm{C}) \mathrm{O}) \mathrm{C}) \mathrm{C}) \mathrm{C}$ \\
Piperlongumine & $\mathrm{COC} 1=\mathrm{CC}(=\mathrm{CC}(=\mathrm{C} 1 \mathrm{OC}) \mathrm{OC}) \mathrm{C}=\mathrm{CC}(=\mathrm{O}) \mathrm{N} 2 \mathrm{CCC}=\mathrm{CC} 2=\mathrm{O}$ \\
Piperine & $\mathrm{C} 1 \mathrm{CCN}(\mathrm{CC} 1) \mathrm{C}=\mathrm{O}) \mathrm{C}=\mathrm{CC}=\mathrm{CC} 2=\mathrm{CC} 3=\mathrm{C}(\mathrm{C}=\mathrm{C} 2) \mathrm{OCO} 3$ \\
Quercetin & $\mathrm{C} 1=\mathrm{CC}(=\mathrm{C}(\mathrm{C}=\mathrm{C} 1 \mathrm{C} 2=\mathrm{C}(\mathrm{C}(=\mathrm{O}) \mathrm{C}=\mathrm{C}(\mathrm{C}=\mathrm{C}(\mathrm{C}=\mathrm{C} 3 \mathrm{O} 2) \mathrm{O}) \mathrm{O}) \mathrm{O})$ \\
& $\mathrm{O}) \mathrm{O}$ \\
Kaemferol & $\mathrm{C} 1=\mathrm{CC}(=\mathrm{CC}=\mathrm{C} 1 \mathrm{C} 2=\mathrm{C}(\mathrm{C}(=\mathrm{O}) \mathrm{C} 3=\mathrm{C}(\mathrm{C}=\mathrm{C}(\mathrm{C}=\mathrm{C} 3 \mathrm{O} 2) \mathrm{O}) \mathrm{O}) \mathrm{O}) \mathrm{O})$ \\
Myrecetin & $\mathrm{C} 1=\mathrm{C}(\mathrm{C}=\mathrm{C}(\mathrm{C}(=\mathrm{C} 1 \mathrm{O}) \mathrm{O}) \mathrm{O}) \mathrm{C} 2=\mathrm{C}(\mathrm{C}(=\mathrm{O}) \mathrm{C} 3=\mathrm{C}(\mathrm{C}=\mathrm{C}(\mathrm{C}=\mathrm{C} 3 \mathrm{O} 2)$ \\
& $\mathrm{O}) \mathrm{O}) \mathrm{O}$ \\
Methyl Piperate & $\mathrm{COC}(=\mathrm{O}) \mathrm{C}=\mathrm{CC}=\mathrm{CC} 1=\mathrm{CC} 2=\mathrm{C}(\mathrm{C}=\mathrm{C} 1) \mathrm{OCO} 2$ \\
\hline
\end{tabular}

\section{Specific docking and interaction visualization}

Molecular docking was done using a personal computer with specifications windows 10, 16GB RAM, SSD 210, and a Ryzen $52400 U$ processor. Molecular docking conducted specific site docking with grid box dimension was generated by fixing $x, y, z$. based on previous study as shown in Table 2 [22], [23]. The in 
silico analysis will yield the bonding interactions strength between the ligands with TNF-alpha and VEGFR. The amino acid residue interactions between ligands and target proteins were visualized using the Discovery Studio software [24], [25].

Table 2: Molecular docking coordinate

\begin{tabular}{lllllll}
\hline $\begin{array}{l}\text { Protein } \\
\text { target }\end{array}$ & Center_X & Center_Y & Center_Z & Size_X (Ao) & Size_Y(Ao) & Size_Y (Ao) \\
\hline TNF-Alpha & 20.267 & 69.406 & 37.782 & 20 & 20 & 20 \\
VEGFR & 2.928 & 20.524 & 26.984 & 30 & 30 & 30 \\
\hline TNF-alpha: Tumour necrosis factor alpha, VEGFR: Vascular endothelial growth factor receptor.
\end{tabular}

\section{Results and Discussion}

\section{Pharmacokinetic and anti-inflammatory \\ score}

This study was conducted using some chemical constituents of methanolic extract of $F$. religiosa leaves. The chemical constituents which were analyzed in this study consist of terpenoid, alkaloid, and flavonoid. Those consistent with previous phytochemical analysis [26], [27], [28]. F. religiosa is already known to have multiple biological activities and is famous in herbal medicine. It was noted to reveal several pharmacological activities such as antidiabetic, anti-inflammatory, antioxidant, antimicrobial, analgesic, and anticonvulsant activity [26], [27], [28], [29]. By the molecular docking method, the ability of the ligand to bind to the macromolecule will be revealed by the binding affinity result [19]. This study showed the binding affinities from the interaction between TNF-alpha and VEGFR as target protein with 8 active compounds from F. religiosa (Lupenyl Acetate, Lanosterol, Piperlongumine, Piperine, Quercetin, Kaemferol, Myricetin, and Methyl Piperate).
Following our predictions, all of the substances in Table 3 have anti-inflammatory effects, indicating that they are all can as anti-inflammatory agents. Lanosterol has the greatest likelihood value, followed by Lupenyl Acetate, Myricetin, Quercetin, Kaemferol, Methyl Piperate, Piperlongumine, dan Piperine.

The compound was evaluated for drug similarity using the Lipinski Rule of Five parameters. The hydrogen bond acceptor value is 10, the hydrogen bond donor value is 5 , the molecular weight is 500 Dalton, the $\mathrm{H}_{2} \mathrm{O}$ partition coefficient $(\log P)$ value is 5 , and the molar refractivity is 40-130 [30]. In metabolic processes, the compound that fulfills those principles has a stronger pharmacokinetics and bioavailability profile as found in this study and represented in Table 3. Our investigation discovered that all of the potential compounds that we docked had a high bioavailability, implying that they were similar to drugs and could be taken orally.

\section{Molecular interaction of active constituents}

Our study revealed Fiscus religiosa compounds were found can bind TNF-alpha respectively stronger than native ligand. It denoted that Lupenyl Acetate and TNF-alpha interaction owned the most negative binding affinity with binding affinity $-6.9 \mathrm{Kcal} / \mathrm{mol}$. Lanosterol also shares the same binding affinity as the native ligand with binding affinity $-6.3 \mathrm{Kcal} / \mathrm{mol}$, suggesting that it may suppress the activity of TNF-alpha. The more negative binding affinity, the better is the predicted binding to that target protein [31]. From all the active compounds carried out in this study, the strongest binding interaction to the TNF-alpha was Lupenyl Acetate and Lanosterol. Besides, the F. religiosa compound also binds VEGFR, more negative binding affinity than

Table 3: Pharmacokinetics profile and score predictive properties of fiscus religiosa compound

\begin{tabular}{lllllll}
\hline Compound Name & Molecular Weight & Hydrogen-bond donor & Hydrogen-acceptor & LogP & Criteria of Lipinski & Anti Inflammatory Probabilty Prediction Score \\
\hline Lupenyl acetate & $468.75 \mathrm{~g} / \mathrm{mol}$ & 0 & 2 & 7.67 & Yes & 0,737 \\
Lanosterol & $426.72 \mathrm{~g} / \mathrm{mol}$ & 1 & 1 & 7.42 & Yes & 0.745 \\
Piperlongumine & $317.34 \mathrm{~g} / \mathrm{mol}$ & 0 & 5 & 1.96 & Yes & 0.435 \\
Piperine & $285.34 \mathrm{~g} / \mathrm{mol}$ & 0 & 3 & 3.04 & Yes & 0.314 \\
Quercetin & $302.24 \mathrm{~g} / \mathrm{mol}$ & 5 & 7 & 1.23 & Yes & 0.689 \\
Kaemferol & $286.24 \mathrm{~g} / \mathrm{mol}$ & 4 & 6 & 1.58 & Yes & 0.676 \\
Myrecetin & $318.24 \mathrm{~g} / \mathrm{mol}$ & 6 & 8 & 0.79 & Yes & 0.720 \\
Methyl Piperate & $232.23 \mathrm{~g} / \mathrm{mol}$ & 0 & 4 & 2.62 & Yes & 0.527 \\
\hline
\end{tabular}

Table 4: The binding affinity of ficus religiosa compound with TNF-alpha and VEGFR

\begin{tabular}{|c|c|c|c|c|}
\hline \multirow[t]{2}{*}{ Ligand type } & \multirow[t]{2}{*}{ No. } & \multirow[t]{2}{*}{ Ligand Name } & TNF- $\alpha$ & VEGFR \\
\hline & & & Binding affinity $(\mathrm{kcal} / \mathrm{mol})$ & Binding affinity $(\mathrm{kcal} / \mathrm{mol})$ \\
\hline \multirow[t]{4}{*}{ Control } & 1. & 6,7-Dimethyl-3-[(Methyl \{2-[Methyl(\{1-[3-(Trifluoromethyl) & -6.3 & \\
\hline & & Phenyl]-1h-Indol-3-Yl\} Methyl) Amino] Ethyl\} Amino) & & \\
\hline & & Methyl]-4h-Chromen-4-One (PDB ID: 2AZ5) & & \\
\hline & 2. & $\mathrm{~N}$-(4-chlorophenyl)-2-[(pyridin-4-ylmethyl) amino] benzamide & & -9.4 \\
\hline \multirow{8}{*}{ Natural Compound } & 1. & Lupenyl Acetate & -6.9 & -8.1 \\
\hline & 2. & Lanosterol & -6.3 & -9 \\
\hline & 3. & Piperlongumine & -5.5 & -7.7 \\
\hline & 4. & Piperine & -5.8 & -9.5 \\
\hline & 5. & Quercetin & -5.7 & -8.5 \\
\hline & 6. & Kaemferol & -5.6 & -8.5 \\
\hline & 7. & Myricetin & -5.6 & -8.1 \\
\hline & 8. & Methyl Piperate & -5.3 & -8.0 \\
\hline
\end{tabular}


control. It was Piperine can bind VEGFR with binding affinity $-9.5 \mathrm{Kcal} / \mathrm{mol}$ (Table 4 ). The molecule with the strong binding energy will exhibit constant temperature and pressure to give better effect [25], [32].

Hydrogen and/or Hydrophobic bonds would also be developed in the ligand-macromolecule interaction. The bonds were intermolecular interactions essential in stabilizing ligands in a conformational setting of the macromolecule structure [33]. The hydrogen bond has a vital role in facilitating ligandprotein interaction and the protein folding process [34]. The number of hydrogen bonds also include in the parameter of empirical analysis in molecular docking study [35]. For comparative purposes, we utilized natural ligand inhibitors from the PDB website. Lupenyl Acetate and Lanosterol bind to the TNF-alpha in the same location as the natural ligand inhibitor, and so may have the same action. Similarly, Piperine and natural ligands VEGFR have same binding site interaction (Figure 1). Additionally, the amino acid residues have an effect on its location in the binding domain of the target protein and the type of chemical interactions [36].

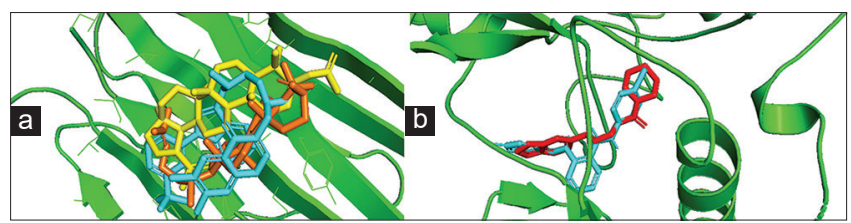

Figure 1: Binding site of Tumour necrosis factor alpha (a) and vascular endothelial growth factor receptor (b). control ligands (cyan), Piperine (red), Lupenyl acetate (yellow), and Lanosterol (orange)

Lupenyl Acetate and TNF-alpha interaction can form hydrogen bonds with the hydrophobic bonds with Leu57, Tyr59, Tyr151, and Ile155. While Lanosterol can bind to the TNF-alpha by the formation of the residues Leu57, Tyr59, Try119, and Tyr151, as seen in (Figure 2). Lupenyl Acetate and Lanosterol, which have the highest binding affinity, can inhibit the TNF-alpha. Meanwhile, Piperine forms hydrophobic connections with Leu833, Val841, Ala859, Leu882, Val891, Val892, Val909, Tyr911, Leu1013, His1020,
Leu1029, Cys1039, and Phe1041 (Figure 3). Thus, F. religiosa possesses significant anti-inflammatory potential due to its ability to inhibit the TNF-alpha and VEGFR.

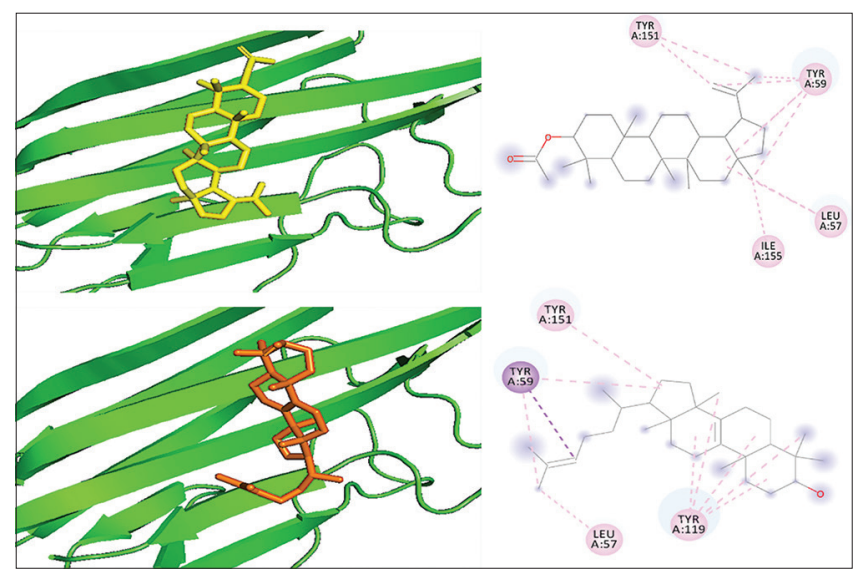

Figure 2: Interaction visualization between Ligands and Tumour necrosis factor alpha. Lupenyl acetate (yellow) and Lanosterol (orange)

Diabetes is a complex metabolic disorder affecting multi-organ systems. Various research has been explained multiple pathogenesis and risk factors in the natural history of DM. However, today's evidence has shown that inflammation is the main pathway in the pathophysiology of DM. The inflammatory cells release specialized substances, which include inflammatory cytokines to mediate the inflammatory process. The number of inflammatory cytokines which are involved in the pathogenesis is extensively large. Several cytokines that are implicated in the inflammation process are the innate inflammatory cytokines TNF-alpha and VEGFR [37], [38]. Impaired wound healing in diabetic become our concern in this study.

We discovered in our study that Lupenyl Acetate, Lanosterol, and Piperine have antiinflammatory effects through inhibition of TNF-alpha and VEGFR, suggesting that it may have promise as a therapeutic candidate in the wound healing process in patients suffering from diabetes. To ensure the

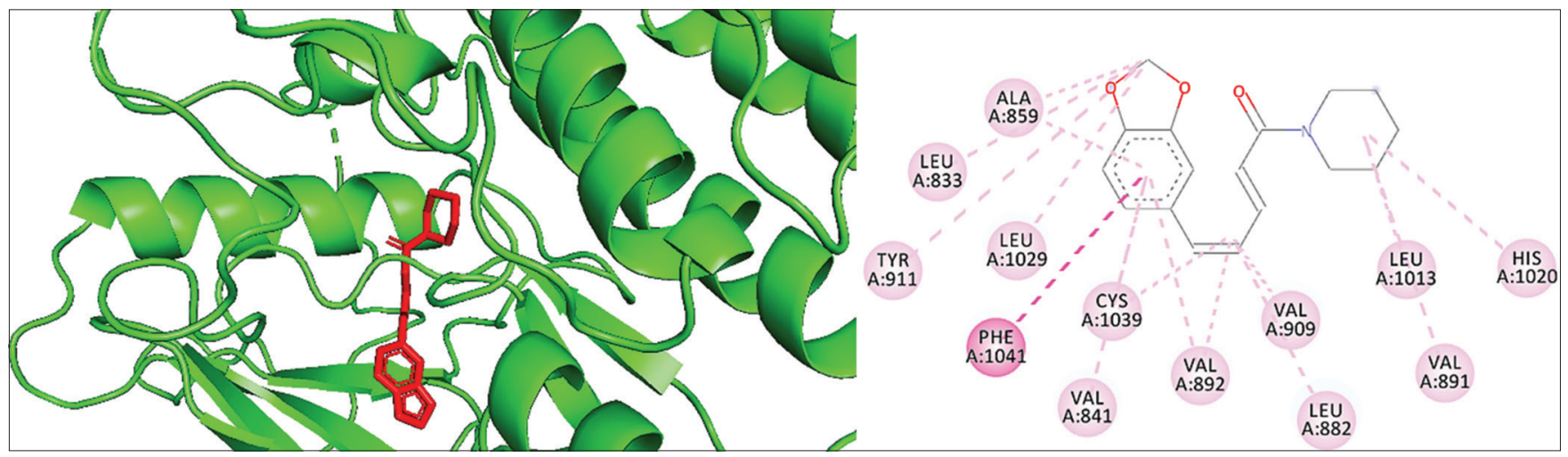

Figure 3: Interaction visualization between Piperine and vascular endothelial growth factor receptor 
effectiveness and safety of the medication, however, more study is necessary.

\section{Conclusions}

In sum, Lupenyl Acetate, Lanosterol, and Piperine have anti-inflammatory effects through inhibition of TNF-alpha and VEGFR. These compounds have good pharmacokinetics. Lupenyl Acetate, Lanosterol, and Piperine have potential as therapy for diabetic wounds. Future research study is needed to know the effectivity and toxicity as diabetic wounds treatment.

\section{References}

1. Sasongko MB, Widyaputri F, Agni AN, Wardhana FS, Kotha S, Gupta $\mathrm{P}$, et al. Prevalence of diabetic retinopathy and blindness in Indonesian adults with Type 2 diabetes. Am J Ophthalmol. 2017;181:79-87. http://doi.org/10.1016/j.ajo.2017.06.019 PMid:28669781

2. Husen SA, Syadzha MF, Setyawan MF, Pudjiastuti P, Ansori AN, Susilo RJ, et al. Evaluation of the combination of Sargassum duplicatum, Sargassum ilicifolium, Abelmoschus esculentus, and Garcinia mangostana extracts for open wound healing in diabetic mice. Syst Rev Pharm. 2020;11:888-92.

3. Salazar JJ, Ennis WJ, Koh TJ. Diabetes medications: Impact on inflammation and wound healing. J Diabetes Complications. 2016;30(4):746-52. http://doi.org/10.1016/j. jdiacomp.2015.12.017

PMid:26796432

4. Sorg H, Tilkorn DJ, Hager S, Hauser J, Mirastschijski U. Skin wound healing: An update on the current knowledge and concepts. Eur Surg Res. 2017;58(1-2):81-94. http://doi. org/10.1159/000454919

PMid:27974711

5. Mitoma $\mathrm{H}$, Horiuchi $\mathrm{T}$, Tsukamoto $\mathrm{H}$, Ueda $\mathrm{N}$. Molecular mechanisms of action of anti-TNF- $\alpha$ agents-comparison among therapeutic TNF- $\alpha$ antagonists. Cytokine. 2018;101:56-63. http://doi.org/10.1016/j.cyto.2016.08.014

PMid:27567553

6. Dokun AO, Chen L, Lanjewar SS, Lye RJ, Annex BH. Glycaemic control improves perfusion recovery and VEGFR2 protein expression in diabetic mice following experimental PAD. Cardiovasc Res. 2014;101:364-72.

7. Ghadigaonkar S, Reddy AG, Kalakumar B, Lakshman M, Rajkumar U. Quantification of total phenolic content, total flavonoid content and evaluation of in vitro free radical scavenging activities in Ficus religiosa Linn. Pharm Innov J. 2021;10(3):84-8.

8. Chandrasekar SB, Bhanumathy M, Pawar AT, Somasundaram T. Phytopharmacology of Ficus religiosa. Pharmacogn Rev. 2010;4(8):195-9. http://doi.org/10.4103/0973-7847.70918 PMid:22228961

9. Araldi E, Fernández-Fuertes M, Canfrán-Duque A, Tang W, Cline GW, Madrigal-Matute $\mathrm{J}$, et al. Lanosterol modulates
TLR4 mediated innate immune responses in macrophages. Cell Rep. 2017;19(13):2743-55. http://doi.org/10.1016/j. celrep.2017.05.093

\section{PMid:28658622}

10. Kim N, Do J, Bae J, Jin HK, Kim JH, Inn KS, et al. Piperlongumine inhibits neuroinflammation via regulating NF-KB signaling pathways in lipopolysaccharide-stimulated BV2 microglia cells. J Pharmacol Sci. 2018;137(2):195-201. http://doi.org/10.1016/j. jphs.2018.06.004

PMid:29970291

11. Tiwari A, Mahadik KR, Gabhe SY. Piperine: A comprehensive review of methods of isolation, purification, and biological properties. Med Drug Discov. 2020;7:100027.

12. Li Y, Yao J, Han C, Yang J, Chaudhry MT, Wang S, et al. Quercetin, inflammation and immunity. Nutrients. 2016;8(3):167. http://doi.org/10.3390/nu8030167

PMid:26999194

13. De Ruyck J, Brysbaert G, Blossey R, Lensink MF. Molecular docking as a popular tool in drug design, an in silico travel. Adv Appl Bioinform Chem. 2016;9:1-11. http://doi.org/10.2147/ AABC.S105289

PMid:27390530

14. Domínguez-Villa FX, Durán-Iturbide NA, Ávila-Zárraga JG. Synthesis, molecular docking, and in silico ADME/Tox profiling studies of new 1-aryl-5-(3-azidopropyl) indol-4-ones: Potential inhibitors of SARS CoV-2 main protease. Bioorg Chem. 2021;106:104497. http://doi.org/10.1016/j.bioorg.2020.104497 PMid:33261847

15. Cho BO, Yin HH, Park SH, Byun EB, Ha HY, Jang SI. Antiinflammatory activity of myricetin from Diospyros lotus through suppression of NF-KB and STAT1 activation and Nrf2-mediated HO-1 induction in lipopolysaccharide-stimulated RAW264.7 macrophages. Biosci Biotechnol Biochem. 2016;80(8):1520-30. http://doi.org/10.1080/09168451.2016.1171697 PMid:27068250

16. Dutra $R C$, Simão da Silva $K A$, Bento $A F$, Marcon $R$, Paszcuk AF, Meotti FC, et al. Euphol, a tetracyclic triterpene produces antinociceptive effects in inflammatory and neuropathic pain: The involvement of cannabinoid system. Neuropharmacology. 2012;63(4):593-605. http://doi. org/10.1016/j.neuropharm.2012.05.008 PMid:22613837

17. Alam W, Khan H, Shah MA, Cauli O, Saso L. Kaempferol as a dietary anti-inflammatory agent: Current therapeutic standing. Molecules. 2020;25:4073.

18. Jing $\mathrm{Z}$, Feng $\mathrm{H}$. Studies on the molecular docking and amino acid residues involving in recognition of substrate in proline iminopeptidase by site-directed mutagenesis. Protein $\mathrm{J}$. 2015;34(3):173-80. http://doi.org/10.1007/s10930-015-9611-4 PMid:25957260

19. Ramírez D, Caballero J. Is it reliable to use common molecular docking methods for comparing the binding affinities of enantiomer pairs for their protein target? Int J Mol Sci. 2016;17(4):525. http://doi.org/10.3390/ijms17040525 PMid:27104528

20. Fu Y, Zhao J, Chen Z. Insights into the molecular mechanisms of protein-ligand interactions by molecular docking and molecular dynamics simulation: A case of oligopeptide binding protein. Comput Math Methods Med. 2018;2018:3502514. http://doi. org $/ 10.1155 / 2018 / 3502514$ PMid:30627209

21. Lagunin A, Filimonov D, Poroikov V. Multi-targeted natural products evaluation based on biological activity prediction with PASS. Curr Pharm Des. 2010;16(15):1703-17. http://doi. org/10.2174/138161210791164063 


\section{PMid:20222853}

22. He MM, Smith AS, Oslob JD, Flanagan WM, Braisted AC Whitty $A$, et al. Small-molecule inhibition of TNF-alpha. Science. 2005;310(5750):1022-5. http://doi.org/10.1126/science.1116304 PMid:16284179

23. Trésaugues $L$, Roos A, Arrowsmith $C$, Berglund H, Bountra $C$, Collins R, et al. Crystal Structure of VEGFR1 in Complex with $\mathrm{N}$-(4-Chlorophenyl)-2-((pyridin-4-ylmethyl)amino)benzamide; 2009. http://doi.org/10.2210/pdb3HNG/pdb

24. Pinzi L, Rastelli G. Molecular docking: Shifting paradigms in drug discovery. Int J Mol Sci. 2019;20(18):4331. http://doi. org/10.3390/ijms20184331

PMid:31487867

25. Syaban MF, Rachman HA, Arrahman AD, Hudayana $N$, Khamid JP, Pratama FA. Allium sativum as antimalaria agent via falciapin protease-2 inhibitor mechanism: molecular docking perspective. Clin Res J Intern Med. 2021;2:130-5.

26. Makhija IK, Sharma IP, Khamar D. Phytochemistry and Pharmacological properties of Ficus religiosa: An overview. Ann Biol Res. 2010;1:171-80.

27. Singh S, Jaiswal S. Therapeutic properties of Ficus religiosa. Int J Eng Res Gen Sci. 2014;2:149-58.

28. Al-Snafi AE. Pharmacology of Ficus religiosa a review. IOSR J Pharm. 2017;7(3):49-60.

29. Biju CR, Jyotisree G, Amita S, Sruthi R. A comparative evaluation of Ficus religiosa with Ficus species for its anti-inflammatory activity: A review. J Appl Pharm Res. 2020;8:13-6.

30. Lipinski CA, Lombardo F, Dominy B, Feeney P. Experimental and computational approaches to estimate solubility and permeability in drug discovery and development settings. Adv Drug Deliv Rev. 2001;46(1-3):3-26. http://doi.org/10.1016/ s0169-409x(00)00129-0 PMid:11259830

31. Dallakyan S, Olson AJ. Small-molecule library screening by docking with PyRx. Chem Biol. 2015;1263:243-50. http://doi. org/10.1007/978-1-4939-2269-7 19
PMid:25618350

32. Kharisma $\mathrm{V}$, Nugraha A. Computational study of ginger (Zingiber officinale) as E6 inhibitor in human papillomavirus Type 16 (HPV-16) infection. Biochem Cell Arch. 2020;20:3155-9.

33. Patil R, Das S, Stanley A, Yadav L, Sudhakar A, Varma AK Optimized hydrophobic interactions and hydrogen bonding at the target-ligand interface leads the pathways of drug-designing. PLoS One. 2010;5(8):e12029. http://doi.org/10.1371/journal. pone.0012029

PMid:20808434

34. Chen D, Oezguen N, Urvil P, Ferguson C, Dann SM, Savidge TC Regulation of protein-ligand binding affinity by hydrogen bond pairing. Sci Adv. 2016;2(3):e1501240. http://doi.org/10.1126/ sciadv. 1501240

PMid:27051863

35. Grinter SZ, Zou X. Challenges, applications, and recent advances of protein-ligand docking in structure-based drug design. Molecules. 2014;19(7):10150-76. http://doi.org/10.3390/ molecules 190710150

PMid:25019558

36. Kharisma VD, Widyananda MH, Ansori ANM, Nege AS, Naw SW, Nugraha AP. Tea catechin as antiviral agent via apoptosis agonist and triple inhibitor mechanism against HIV-1 infection: A bioinformatics approach. J Pharm Pharmacogn Res. 2021;9:435-45.

37. Abdulkhaleq LA, Assi MA, Abdullah R, Zamri-Saad M, TaufiqYap YH, Hezmee MNM. The crucial roles of inflammatory mediators in inflammation: A review. Vet World. 2018;11(5):62735. http://doi.org/10.14202/vetworld.2018.627-635 PMid:29915501

38. Tsalamandris S, Antonopoulos AS, Oikonomou E, Papamikroulis GA, Vogiatzi G, Papaioannou S, et al. The role of inflammation in diabetes: current concepts and future perspectives. Eur Cardiol Rev. 2019;14(1):50-9. http://doi.org/10.15420/ ecr.2018.33.1

PMid:31131037 